УДК 37:929(093.3)

Б. Серадзка-Базюр, доктор габілітований, професор

(Академія "Ігнатіанум" в Кракові, Республіка Польща) sieradzka4@gmail.com

Н. А. Сейко,

доктор педагогічних наук, професор

(Житомирський державний університет імені Івана Франка) sejkona.zdu@gmail.com

ORCID: 0000-0002-6197-9553

\title{
ТЕМПОРАЛЬНІ ХАРАКТЕРИСТИКИ ПЕДАГОГІКИ ВАСИЛЯ СУХОМЛИНСЬКОГО
}

У статті визначено темпоральні характеристики педагогічної теорії і практики педагогічної діяльності Василя Олександровича Сухомлинського. Визначено зв'язок між часом та провідними педагогічними поняттями, щзо знаходять своє місие у теорї В. Сухомлинського - навчанням, вихованням, розвитком особистості дитини. 3'ясовано темпоральний зміст провідних процесуальних характеристик розвитку особистості - діяльності, мислення, поведінки й комунікацій. Встановлено рівні функиіонування темпоральної педагогіки (час як період життя людини; як поняття щзоенного життя особистості; як иңінність). Сформульовано висновок про близькість темпоральних ідей Василя Сухомлинського та Януша Корчака.

Ключові слова: Василь Сухомлинський, темпоральність, педагогічна теорія.

Постановка проблеми дослідження. Зростання темпів щоденного життя кожної особистості, тиск глобальних соціокультурних процесів, нарощування динаміки процесів навчання і виховання в умовах навчальних закладів різного типу і рівнів, трансформації реального та віртуального соціальних середовищ в житті особистості - все це спонукає до теоретичних пошуків в раніше недоторканних 3 точки зору теорії соціалізації особистості наукових площинах. До таких "неходжених" наукових площин можна віднести дослідження в галузі часу, які початково стали об'єктом вивчення представників філософської й природничо-математичних наук, за якийсь час - філології й мистецьких дисциплін, згодом - соціології й психології, проте лише фрагментарно використовуються сучасною педагогікою.

Водночас у класичних педагогічних теоріях XX століття, до яких традиційно відносять педагогічні теорії Антона Макаренка, Василя Сухомлинського, Григорія Ващенка та ін., присутні елементи темпоральності як в окресленні процесуальних характеристик навчання і виховання дітей, так і в педагогічних оцінках результативності навчально-виховного процесу.

Педагогічна спадщина Василя Сухомлинського досить добре вивчена: з точки зору історіографії (Л. Пархета [1], О. Сараєва [2] та ін.), філософії дитинства (Т. Кочубей [3], В. Кравцов [4], М. Чепіль [5] та ін.), педагогіки творчої особистості (М. Антонець [6], Г. Бондаренко [7] та ін.), місця і ролі В. Сухомлинського в світовій педагогічній думці (О. Сухомлинська [8], Л. Цзихуа [9] та ін.), проблем підготовки та діяльності вчителя (Л. Бондар [9], О. Околович [10], В. Радул [11] та ін.). Про роль книжки та художнього слова у вихованні особистості (як їх тлумачив В. О. Сухомлинський) пишуть у своїх працях Л. Заліток [12], Г. Ткаченко [13], Г. Сагач [14] та ін.

Водночас темпоральність як особливий складник педагогічної теорії В. О. Сухомлинського, на нашу думку, залишилася поза увагою вітчизняних учених, що й зумовлює актуальність обраної для дослідження проблеми.

Мета статті - визначити темпоральні характеристики педагогіки Василя Сухомлинського на матеріалі його основних наукових праць.

Виклад основного матеріалу. Складність вивчення феномена часу в педагогічному відношенні визначається, на нашу думку, такими чинниками:

1) інтуїтивно-алогічним характером самого феномена часу;

2) загальнолюдським характером його прояву в різних соціальних середовищах та соціальних ситуаціях;

3) відсутності належного методологічного інструментарію для вивчення феномена часу в педагогічному відношенні;

4) суперечливості означеного феномена в педагогічній площині - його максимальній узагальненості, з одного боку, та вимогах максимальної точності - $з$ іншого.

Як виняток із загального правила розглядати час у педагогіці інструментально (як час проведення занять, час безпосередніх комунікацій дитини або ж їі вільний час в школі та поза їі межами) можна назвати хіба що публікації Л. Абульханової-Славської [15], В. Ільїна [16], де час потрактовано як категорію буття дитини в соціумі. 
Водночас на дослідженні проблеми часу виросли цілі наукові галузі і напрями досліджень, які можна об’єднати під назвою "темпоральні" - темпоральна психологія (психологія часу), теорія поля К. Левіна [17], числова теорія часу Аристотеля, причинна темпоральна теорія К. Юнга і Д. Юма, теорія соціального часу або ж хроносоціологія (Е. Гідденс, Ж. Гурвіч, Н. Еліас та ін.) [18], імплікативна філософія М. Брайчевського [19] та інші. Між тим темпоральні характеристики діяльності, мислення, соціалізації, соціальних комунікацій, цінностей, процесів пізнання, оцінки - тобто притаманні педагогічній науці темпоральні категорії - потребують окремого осмислення й наукового аналізу. До педагогічних досліджень часу можна з певною часткою умовності віднести дослідження Т. Парсонса [20], який вважав час важливою умовою взаємодії між людьми, а на цьому побудував свою соціально-педагогічну теорію.

У зв'язку з педагогічною специфікою часу варто, на нашу думку, розглядати його у зв'язку з кількома рівнями його протікання - як індивідуальний час, груповий та суспільний. Особистісний рівень часу особистості в педагогічному сенсі може бути представлений, насамперед, хронологічною й хронометричною орієнтацією дитини в її соціальному середовищі - сім’і, навчальному закладі, групах ровесників, які представляють груповий та суспільний рівні протікання часу.

Як свідчить аналіз наукового доробку Василя Сухомлинського, час може розглядатися в його наукових працях на трьох основних рівнях:

1 рівень - час як весь період життя особистості (дитини, дорослого); при цьому надважливе значення має проблема ставлення дитини до народження і смерті як крайніх точок буття;

2 рівень - час як поняття щоденного життя людини (школа, родина, коло спілкування та ін. як визначальні темпоральні інститути);

3 рівень - час як аксіологічний феномен (цінність часу; оцінювання часу залежно від віку особистості та ін.).

На першому рівні основоположними поняттями темпорального змісту є поняття "народження", "життя", "смерть". На підставі узагальнення численних наукових праць В. Сухомлинського та інших видатних вітчизняних вчених-педагогів академік О. В. Сухомлинська, виходячи з необхідності наукового обгрунтування педагогічної танатології зазначає, що в період колективізації і особливо після другої світової війни тема часу як періоду життя (і смерті) особистості стала тлумачитися по-іншому з огляду на смерть як подвиг. ... Добре вихована дитина мала бути підготовлена до життя і смерті на завдання партії.

Досить часто педагогічну теорію Василя Сухомлинського порівнюють зі здобутками теорії і практики діяльності Януша Корчака (див., наприклад, роботи К. Рейвенскрофта [21], О. Сухомлинської [22]). Зазначимо, однак, що в темпоральних питаннях ці педагоги суттєво відрізняються один від одного; у Я. Корчака читаємо: "Побоюючись, аби смерть не забрала у нас дитини, забираємо у дитини життя; не бажаючи, аби дитина померла, не даємо їй жити" [23: 57)]. Натомість В. Сухомлинський пише у своїй відомій праці "Як виховати справжню людину": Смерть людини - не просто згасання і припинення життєвих процесів. Це подія у процесі життя поколінь, що називається наступністю" [24: 47-48]. Деталізуючи своє бачення часу на його щоденному рівні, видатний педагог пише: "Діти живуть своїми поняттями про добро і зло, честь і ганьбу, про людську гідність. ... Вони мають свої критерії краси, навіть свій вимір часу: у дитинстві день здається роком, а рік - вічністю" [25: 58].

Як стверджує у своїх наукових пошуках В. Горбунов [26: 8], осмислення часу має кілька напрямів: об'єктивістський (абсолютизація часу), проміжний (фрагментарна відносність часу), та суб' єктивістський (час як атрибут індивідуального досвіду і свідомості). Ці напрями сформувалися ще за часів античності й у більш пізні періоди залічували до своїх шерег тих чи інших науковців, що розвивали об'єктивістські чи суб’єктивістські позиції. У науковому доробку представників обох напрямів час

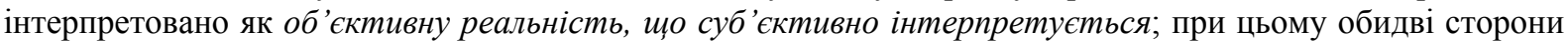
означеної реальності взаємодоповнювані, а не суперечливі одна стосовно іншої.

Педагогічна специфіка часу спонукає до окреслення його основних функцій у процесі навчання та виховання, і загалом у процесі соціалізації дитини. Такими функціями можна вважати:

1) Організаційну, завдяки якій відбувається впорядкування процесу соціалізації особистості, переважно внаслідок встановлення ієрархії окремих подій та їх впливу на соціалізаційні процеси. Так, перші дні перебування дитини в дитячому садочку чи школі можуть задати новий напрям соціалізації (залежно від ефективності дії агентів та провідників соціалізації) і тому такі події часто вважаються вирішальними в темпоральному відношенні.

2) Інтеграційну, що визначає процеси синхронізації в часовому відношенні; так, у процесі соціалізації синхронно може відбуватися розвиток кількох соціальних ролей і соціальних статусів дитини (роль сина, учня, друга; високий соціальний статус в середовищі однолітків і занижений - у власній родині та ін.).

3) Соціально-пізнавальну - що визначає швидкість, глибину, ефективність пізнавальних процесів у часі і просторі соціалізації дитини; так, зміст навчального матеріалу засвоюється різними дітьми 3 різним успіхом упродовж одного й того самого часу; так само по-різному відбувається інтеріоризація зовнішньої соціальної інформації на різних вікових етапах та в різних соціальних умовах. 
4) Координаційну, що відображає своєчасність тієї чи іншої події в часі і просторі. Наприклад, традиційно вважається, що успішна соціалізація дитини в шкільному колективі залежить від того, чи є це колектив однолітків (адже дитина може потрапити до школи на рік пізніше чи раніше встановленого терміну). Так само по-різному старшокласники оцінюють своєчасність першого статевого досвіду, окремих девіантних проявів поведінки (першої цигарки, першого факту вживання алкоголю тощо).

5) Соціально-рефлексивну, яка дає можливість встановити роль соціальної пам'яті в процесі соціалізації особистості дитини та глибину інтеріоризацій них процесів, що відбуваються при цьому.

Крім означених вище понять, важливий темпоральний зміст для педагогічної науки в інтерпретації Василя Сухомлинського має поняття віку дитини. Час визначає соціалізаційну диференціацію біологічного зростання дитини, сукупність соціальних ролей, які відіграє дитина в процесі соціалізації, формуючи таким чином матрицю процесу соціалізації особистості. У зв'язку 3 цим великий педагог вирізняє особливу вікову групу - "дитинство" - і наполягає на ії особливих характеристиках. Доречним у цьому відношенні його порівняння з позицією Я. Корчака, котрий зазначає: "Діти відрізняються від дорослих, в їхньому житті чогось бракує, а чогось є більш аніж в нашому, але це відмінне від нашого дитяче життя є реальністю, а не привидом. Що нами було зроблено, щоб пізнати це життя і створити умови, в яких могло би існувати і розвиватися дитинство?" [23: 60]. Схожі міркування бачимо у В. Сухомлинського: "Моя турбота про дитину починається з того, як харчується і спить дитина, яке іiі самопочуття, як вона бере участь у грі, скільки годин протягом дня перебуває на свіжому повітрі, чи має улюблену працю і скільки часу присвячує їй дитина" [27: 108]. Відзначаючи вікові особливості дитячого часу, педагог водночас переконаний у величезному його прогностичному значенні: "Ми приходимо в цей світ маленькими для того, щоб залишити слід на землі, прожити життя справжніми людьми. Людське життя дуже коротке. Людина смертна: врешті-решт ми відходимо в небуття. Одночасно людина безсмертна: твоє безсмертя в тому, що зможеш створити щось важливе для інших людей" [24: 25].

Згідно з висновками В. Сухомлинського можемо констатувати, що різноманітні агенти й провідники соціалізації особистості в дитячому віці (родина, школа, формальні і неформальні групи й об'єднання ровесників) мають свої темпоральні характеристики на рівні сприйняття часу (часу спілкування, вільного часу, часу дозвілля, часу пізнання і т.п.) і дають можливість структурувати:

1) рівень і глибину освоєння часу - як співвідношення інтеріоризаційних і екстеріоризаційних процесів у дитини на кожному віковому етапі;

2) ранжування темпоральних цінностей - тобто визначення пріоритетних способів i форм освоєння часу (навчального, вільного, пізнавального, комунікативного тощо);

3) спосіб вироблення темпоральних стратегій (тобто способів освоєння часу залежно від обраної життєвої стратегіï);

4) спрямованість темпоральних орієнтацій (надання переваги тому чи іншому способу освоєння часу).

У зв'язку з цим особливого значення набуває ставлення В. Сухомлинського до режиму навчання, праці і відпочинку дитини. Режим, на думку видатного вченого - це запорука не лише успішного навчання дитини, але й іiі розвитку упродовж всього часу дорослішання в шкільному та позашкільному середовищі. При цьому педагог віддає належне співвідношенню навчального і вільного часу і досить поособливому тлумачить таке співвідношення, зазначаючи: "Відсутність праці під час уроку, відсутність розумової діяльності там, де вона повинна бути - головна причина того, що дитина не має вільного часу" [24: 75]. При цьому вчений виділив кілька, на його думку, неприпустимих речей, які руйнують ефективний режим часу дитини в школі і поза нею, а заодно порушують весь процес розвитку дитини: "Зовсім неприпустимо, щоб одразу після уроків учень протягом кількох годин виконував домашнє завдання, чи по суті був зайнятий такою само інтенсивною розумовою працею, як і в школі. ... 10-12 годин щоденного сидіння над книжками, слухання, коментування, пригадування, відтворення - це понад сили, це тяжка праця, яка врешті-решт знищує сили дитини, викликає байдужість до знань, призводить до того, що дитина має лише уроки і не має інтелектуального життя" [27: 141].

Означені вище особливості структурування часу дитини в контексті окреслення режиму навчання, праці і відпочинку у спадщині В. Сухомлинського дають можливість стверджувати також індивідуальну, а не лише вікову специфіку сприйняття й освоєння часу. Ця специфіка пов'язана, на нашу думку, 3 розумінням вченим індивідуальних психологічних особливостей кожної дитини - рівнем розвитку іiі основних психічних процесів, емоційності, сформованістю здатності до комунікативної взаємодії в часі і просторі, рівнем сформованості соціальної мобільності та ін. Індивідуальне сприйняття часу в процесі навчання і виховання дитини виявляє себе в тому, як дитина переживає час, відчуває його, вміє його витрачати, усвідомлює цінність часу - як робочого (навчального), так і вільного. Ця індивідуальна матриця часу залежить також від локальних соціокультурних детермінант (насамперед, сімейних), що дають можливість встановлювати аксіологічний ряд "минуле-теперішнє-майбутнє", задати певні темпоральні зразки життєдіяльності дитини (співвідношення вільного й зайнятого часу, його діяльнісна насиченість тощо), окреслити співвідношення "самочасу" і часу взаємодії з навколишнім середовищем 
соціалізації. У педагогіці В. Сухомлинського це співвідношення може бути представлене такою цитатою: "Не дивуйтеся того, що під час уроку, задивившись, як на стіні класу віддзеркалюється тінь дерева, дитина не чує абсолютно нічого з того, що їй говорить вчитель. Так, дитина не чує, тому що ії впіймав інший час - час дитинства, який вона відчуває зовсім інакше, аніж дорослі. Не кричіть на неї, не виставляйте перед усім класом як неуважну, нездатну дитину. Тихенько підійдіть до учня, візьміть його за руку, пересадіть 3 прекрасного човна дитинства до корабля пізнання. ... А найважливіше - нехай не буде вам шкода часу аби пересісти до дитини до іiі дитячого човна, побути з нею, подивитися на світ іiі очима" [28: 495-496].

Отож, у науковому доробку В. Сухомлинського вводяться й інтерпретуються окремі темпоральні поняття - подія, час дитинства, пам'ять, зміни, розвиток, режим та ін. На особливу увагу в контексті темпоральної педагогіки в творчості В. Сухомлинського, на нашу думку, заслуговує поняття соиіальної nам'яті, що поєднує минуле, теперішнє і майбутнє і дає можливість визначити зміст та специфіку індивідуальних соціально-темпоральних змін, що відбуваються, як правило, внаслідок накопичення множини окремих подій, які впливають на соціалізацію дитини, і перехід цих кількісних змін у якісні. Таким чином, індивідуальний процес навчання і виховання, репрезентований у педагогічній спадщині В. Сухомлинського $є$ не лише темпоральним, але й діалектичним. Різноманітні типи подій в житті дитини (взаємодія чи конфлікти в сім’і, залучення до груп ровесників, події дружби і любові, навчальні події, вчинки дитини, досягнення успіху як подія, переживання того чи іншого факту в житті дитини згідно з її віковими та індивідуально-психологічними особливостями і т.п.) дають певний кумулятивний ефект, що й підтверджує означений діалектичний зв'язок.

У своїй творчості вчений орієнтувався не лише на теперішній час, а й переживання дітьми подій минулого, представлених вчителями - подвигів у часи воєн, традицій своєї родини, спогадів своїх близьких про пережиті події в минулому тощо. 3 цим пов'язані у педагога поняття завершеності людського життя і потенційного безсмертя, що, до речі, зовсім не співпадало з традиціями радянської педагогіки про співвідношення минулого, теперішнього і майбутнього. Так, Василь Олександрович пише: "Людина народжується не для того, щоб зникнути без сліду невідомою істотою. Людина залишає слід після свого життя, насамперед, в людині. ... В цьому наше безсмертя. Живемо для того, щоб відтворитися в синові чи дочці, жити їх успіхами і їхньою працею" [24: 50].

Таким чином, пам'ять як темпоральне поняття у спадщині В. Сухомлинського відображає зв'язок 3 минулим, теперішнім і майбутнім у ході соціалізації відображає всі три названі перспективи, тому їх можна інтерпретувати таким чином:

1) орієнтація на минуле дає можливість інтеріоризувати події минулого відповідно до їх індивідуального сприйняття дитиною;

2) події минулого, завдяки кумулятивному ефекту, певним чином впливають на інтеріоризацію наявних на теперішній час подій та згодом екстеріоризувати їх;

3) інтеріоризація подій теперішнього дозволяє говорити про прогностичний характер соціалізації в майбутньому, тобто екстеріоризацію майбутнього дитини в соціальному становленні й розвитку. Оцінка минулого й майбутнього в житті дитини відбувається, таким чином, з позицій нинішнього для кожної дитини часу.

Використання темпоральних характеристик пам’яті у теорії і практиці діяльності В. Сухомлинського дає можливість говорити про подієвий характер часу в його спадщині. Водночас подієвість не є єдиною темпоральною характеристикою розвитку особистості; особливої уваги заслуговує також сприйняття часу кожною дитиною зокрема, тобто суб'єктивне відображення в свідомості дитини тривалості, швидкості, послідовності подій і явищ. Сприйняття дитиною часу відноситься науковцями (Б. Цуканов [29], Л. Біленька [30], М. Немировська [31], Т. Тушнова [32]) до соціально-перцептивних якостей особистості. При цьому темпоральність виражається в кількох основних аспектах:

1) хронометричному, тобто відліку часу за допомогою заданих його відрізків (наприклад, тривалості уроку, заняття, доби, навчального дня і т.п.);

2) хронологічному - способу відображення часу залежно від загальноприйнятих темпоральних явищ: віку (кількості років), пори року та ін.; хронологія соціалізації відносить нас до таких понять, як соціальний вік, етапи соціалізації;

3) хроногнозичному, тобто суб'єктивному індивідуалізованому сприйняттю часу, що дає можливість суб' єктивно переживати ті чи інші події залежно від їх значущості, очікуваності, емоційності тощо; так, щоденну перевірку домашніх завдань батьками діти сприймають індивідуально - від спокійного очікування до стресового стану внаслідок непрогнозованих наслідків цієї події.

У зв'язку з цим можемо визначити провідні темпоральні характеристики педагогічної спадщини В. О. Сухомлинського, а саме:

1) еластичність і гнучкість часу як педагогічного феномена у працях вченого;

2) відзначення ролі спільного часу в діадах "вчитель-учень", "учень-батьки", "учень-учень";

3) окреслення вільного часу як часу на розвиток особистості дитини - як у школі, так і поза нею. 
Своєрідним підсумком темпоральних характеристик педагогічної спадщини В. Сухомлинського можуть стати його слова: "Виховує кожна хвилина життя і кожен куточок землі, кожна людина, 3 якою дитина має можливість зустрітися навіть випадково" [33: 15].

Висновки. Таким чином, нами зроблено спробу визначити темпоральні характеристики навчання $\mathrm{i}$ виховання дитини у педагогічній спадщині Василя Сухомлинського залежно від сутності, функцій, структурування часу як всезагальної категорії буття людини. Визначено провідні темпоральні поняття педагогіки В. Сухомлинського - час дитинства, зміна, режим, подія, пам'ять і т.п. Обгрунтовано хронометричні, хронологічні та хроногнозичні особливості педагогічної спадщини вченого. Перспективу подальших досліджень вбачаємо у науковому обгрунтуванні темпоральних цінностей особистості в процесі соціалізації.

\section{СПИСОК ВИКОРИСТАНИХ ДЖЕРЕЛ ТА ЛІТЕРАТУРИ}

1. Пархета Л. П. Історіографія вивчення спадщини В. О. Сухомлинського / Л. П. Пархета // Витоки педагогічної майстерності. Серія Педагогічні науки. - 2009. - Вип.6. - С. 31-37.

2. Сараєва О.В. Педагогічна система В. О. Сухомлинського в науковому доробку вітчизняних учених / О. В. Сараєва : автореф. ... канд.. пед. н. : 13.00.01. "Загальна педагогіка та історія педагогіки". - К., 2007. $20 \mathrm{c}$.

$\begin{array}{llllll}\text { 3. Кочубей Т. Д. Філософія дитинства в педагогічній спадщині } & \text { В. О. Сухомлинського / }\end{array}$ Кочубей Тетяна Дмитрівна : дис. .... канд. пед. н. : 13.00.01. - Умань, 2001. - 216 с.

4. Кравцов В. О. Принцип природовідповідності виховання у педагогічній спадщині В. О. Сухомлинського / Кравцов Віталій Олександрович : дис. ... канд.. пед. н. : 13.00.01. - Кіровоград, 2001. - 201 арк.

5. Чепіль М. М. Ідея добра і любові у педагогічній спадщині Василя Сухомлинського / М. М. Чепіль // Молодь і ринок. - № 1 (84). - 2012. - С. 37-41.

6. Антонець М. Я. Педагогічна спадщина В.О.Сухомлинського в сучасній освітньо-виховній теорії і практиці / М. Я. Антонець // Педагогіка і психологія. - Вісник АПН України. - 1994. - № 1. - С. 165-167.

7. Бондаренко Г. Л. Формування творчої особистості молодшого школяра в педагогічній спадщині В. О. Сухомлинського / Г. Л. Бондаренко : автореф. ... канд.. пед. н. : 13.00.01. "Теорія і історія педагогіки". - K., 1999. $-18 \mathrm{c}$.

8. Сухомлинська О. В. Василь Сухомлинський в зарубіжжі / О. В. Сухомлинська // Початкова школа. - 1998. № 9. - C. 5-10.

9. Бондар Л. С. Педагогічна культура вчителя як основа його професійної компетентності у творчій спадщині В. О. Сухомлинського / Л. С. Бондар // Педагогіка і психологія. - 2006. - № 3. - С. 13-18.

10. Околович О. Професійна культура вчителя крізь призму теорій Василя Сухомлинського / Олександр Околович // Людинознавчі студії. Педагогіка. - 2014. - Вип. 29 (1). - С. 114-124.

11. Радул В. В. Розвиток поглядів В. О. Сухомлинського стосовно особистості сучасного вчителя / В. В. Радул, О. С. Радул // Наукові записки. - Вип. 52. - Ч. 1. - 2003. - 36 с.

12. Заліток Л. М. В.Сухомлинський про роль книжки у вихованні духовної особистості / Л. М. Заліток. - Режим доступу : http://journals.dnpb.gov.ua/article/view/73256/74278.

13. Ткаченко Г. М. Виховання школярів засобами слова у творчій спадщині В. О.Сухомлинського / Ткаченко Галина Миколаївна : дис. ... канд.. пед. н. : 13.00.01. - К., 1999. - 198 с.

14. Сагач Г. М. В. О. Сухомлинський про мистецтво слова педагога / Г. М. Сагач // Слово животворяще (духовні засади педагогічної риторики) : [навчальний посібник]. - К. : Пошук, 2000. - С. 215-223.

15. Абульханова-Славская Л. А. Время личности и время жизни / Л. А. Абульханова-Славская, Т. Н. Березина. СПБ. : Алтейя, 2001. - 304 с.

16. Ильин В. И. Социальное время и социальное пространство / В. И. Ильин // Социальное неравенство / Центр социологического образования института социологии РАН. - М. : Изд-во "Институт социологии РАН", 2000. - C. $58-65$.

17. Левин К. Топология и теория поля. Определение понятия "поле в данный момент" / Курт Левин // История психологии (10-30-е гг. Период открытого кризиса) : Тексты / Под ред. П. Я. Гальперина, А. Н. Ждан. - 3-е изд. - Екатеринбург : Деловая книга, 1999. - С. 230-260.

18. Gurvitch G. The Spectrum of Social Time / Gurvitch G. - Holland : D. Reidel Publishing company, 1964. - 86 p.

19. Агеєв В. В. Михайло Брайчевський: імплікативна філософія та філософія часу / В. В. Агеєв // Наукові записки НаУКМА. - 2002. - Т. 20 : Історичні науки : у 2ч. Ч.1. - С. 75-76.

20. Theory of Society / ed. by T. Parsons, E. Shils, K. D. Naegele, J. R. Pitts. N.Y. : The Free Press, 1961.

21. Рейвенскрофт К. Встреча с чудом. Ребенок откликается на природку / Кельвин Рейвенскрофт // Філософія дитинства Януша Корчака. Фундаментальні потреби дитини в сучасному суспільстві : [збірник матеріалів Міжнародної наукової конференції з педагогіки та дитячої психології]. - К. : Дух і літера, 2017. - С. 55-72.

22. Сухомлинська О. В. Філософія дитинства Януша Корчака: як ми розуміємо ії сьогодні / Ольга Сухомлинська // Філософія дитинства Януша Корчака. Фундаментальні потреби дитини в сучасному суспільстві : [збірник матеріалів Міжнародної наукової конференції з педагогіки та дитячої психології]. - К. : Дух і літера, 2017. C. $22-29$.

23. Korczak J. Jak kochac dziecko / Korczak Janusz. - Warszawa, 2012. - 174 s.

24. Сухомлинський В. О. Як виховати справжню людину / В. О. Сухомлинський // Вибрані твори : у 5т. - К. : Радянська школа, 1977. - Т. 2 - 149 с.

25. Сухомлинский В. Неотложные проблемы теории и практики воспитания / В. Сухомлинский // Народное образование. - 1961. - №. 10. - С. 54-61. 
26. Горбунов В. Е. Социология времени: теоретико-методологические аспекты анализа : автореф. дисс... канд..социол.н. : 22.00 .01 - "Теория, методология и история социологии" / Владимир Евгеньевич Горбунов. Саратов, 2000. - $22 \mathrm{c}$.

27. Сухомлинський В. О. Серце віддаю дітям / Василь Сухомлинський. - К. : Радянська школа, 1972. - 244 с.

28. Сухомлинський В. О. Сто порад вчителеві / В. О. Сухомлинський // Вибрані твори : В 5т. - Т. 2. - К. : Радянська школа, 1976. - 661с.

29. Цуканов Б. И. Качество "внутренних часов" и проблема интеллекта / Б. И. Цуканов // Психологический журнал. - 1991. - Т. 12. - № 3. - С. 38-44.

30. Беленькая Л. Я. К вопросу о восприятии временной длительности и его нарушениях / Л. Я. Беленькая // Исследования по психологии восприятия. - М. - Л., 1948. - С. 342-358.

31. Немировская М. А. Развитие чувства времени: психоаналитическая точка зрения / М. А. Немировская // Журнал практической психологии и психоанализа № 2 июня 2003. - № 6. - С. 15-19.

32. Тушнова Т. В. О памяти на время у детей различного школьного возраста / Т. В. Тушнова // Физиологические механизмы восприятия и оценки времени : Учёные записки Башкирского государственного университета. - 1968. - Вып. 24. Серия биологическая - № 3. - С. 128-133.

33. Сухомлинський В. О. Про виховання / В. О. Сухомлинський // Вибрані твори: В 5т. - Т. 2. - К. : Радянська школа, 1976. - $661 \mathrm{c}$.

\section{REFERENCES (TRANSLATED \& TRANSLITERATED)}

1. Parkheta L. P. Istoriohrafiia vyvchennia spadshchyny V. O. Sukhomlynskoho [Historiography Investigation of V. O. Sukhomlynsky's Heritage] / L. P. Parkheta // Vytoky pedahohichnoi maisternosti. Seriia Pedahohichni nauky [The Sources of Pedagogical Skills. Series Pedagogy]. - 2009. - Vyp. 6. - S. 31-37.

2. Saraieva O. V. Pedahohichna systema V. O. Sukhomlyns'koho v naukovomu dorobku vitchyznianykh uchenykh [Pedagogical System of V. O. Sukhomlinsky in Scientific Heritage of Native Scholars] / O. V. Saraieva : avtoref. ... kand.. ped. n. : 13.00.01. "Zagal'na pedagogika ta istoriia pedagogiky". - K., 2007. - 20 s.

3. Kochubei T. D. Filosofiia dytynstva v pedahohichnii spadshchyni V. O. Sukhomlynskoho [The Philosophy of Childhood in the Pedagogical Works by V. O. Sykhomlynsky] / Kochubei Tetiana Dmytrivna : dys. ... kand. ped. n. - Uman', 2001. - $216 \mathrm{~s}$.

4. Kravtsov V. O. Pryntsyp pryrodovidpovidnosti vykhovannia u pedahohichnii spadshchyni V. O. Sukhomlynskoho [The Principle of the Nature-Accordance of Upbringing in Pedagogical Heritage of V. O. Sukhomlynsky]/ Kravtsov Vitalii Oleksandrovych : dys. ... kand.. ped. n. : 13.00.01. - Kirovohrad, 2001. - 201 ark.

5. Chepil M. M. Ideia dobra i liubovi u pedahohichnii spadshchyni Vasylia Sukhomlynskoho [Idea of Goodness and Love in Vasyl Sukhomlynsky Pedagogical Inheritance] / M. M. Chepil // Molod' i rynok [Youth and Market]. - № 1 (84). - 2012. - S. 37-41.

6. Antonets M. Ya. Pedahohichna spadshchyna V. O. Sukhomlynskoho v suchasnii osvitno-vykhovnii teorii i praktytsi [V. O. Sukhomlinsky's Pedagogical Heritage in Modern Instructional-Educational Theory and Practice]/ M. Ya. Antonets // Pedahohika i psykholohiia [Pedagogy and Psychology]. - Visnyk APN Ukrainy. - 1994. - № 1. - S. 165-167.

7. Bondarenko H. L. Formuvannia tvorchoi osobystosti molodshoho shkoliara $\mathrm{v}$ pedahohichnii spadshchyni V. O. Sukhomlynskoho [The Formation of the Younger Pupils' Creative Personality in the Pedagogical Legacy of V. O. Sukhomlynsky] / H. L. Bondarenko : avtoref. ... kand.. ped. n. : 13.00.01. "Teoriia i istoriia pedagogiky". K., 1999. $-18 \mathrm{~s}$.

8. Sukhomlynska O. V. Vasyl Sukhomlynskyi v zarubizhzhi [Vasyl Sukhomlynsky Abroad] / O. V. Sukhomlynska // Pochatkova shkola [Primary School]. - 1998. - № 9. - S. 5-10.

9. Bondar L. S. Pedahohichna kul'tura vchytelia yak osnova yoho profesiinoi kompetentnosti u tvorchii spadshchyni V. O. Sukhomlynskoho [Teachers' Pedagogic Culture as Basis of His Professional Competence in V. O. Sukhomlynsky's Pedagogical Heritage]/ L. S. Bondar // Pedahohika i psykholohiia [Pedagogy and Psychology]. - 2006. - № 3. - S. 13-18.

10. Okolovych O. Profesiina kul'tura vchytelia kriz' pryzmu teorii Vasylia Sukhomlynskoho [Teacher's Professional Culture through the Prism of Vasyl Sykhomlynsky's Theory]/ Oleksandr Okolovych // Liudynoznavchi studii. Pedahohika [Human Studies. Pedagofy]. - 2014. - Vyp. 29 (1). - S. 114-124.

11. Radul V. V. Rozvytok pohliadiv V. O. Sukhomlynskoho stosovno osobystosti suchasnoho vchytelia [Development of V. O. Sykhomlynsky's Outlook in Relation to Modern Teachers' Personality] / V. V. Radul, O. S. Radul // Naukovi zapysky [Scientific Notes]. - Vyp. 52. - Ch. 1. - 2003. - $36 \mathrm{~s}$.

12. Zalitok L. M. V. Sukhomlynskyi pro rol' knyzhky u vykhovanni dukhovnoi osobystosti [V. Sykhomlynsky about the Role of Book in Upbringing a Spiritual Person]/ L. M. Zalitok. - Rezhym dostupu : http://journals.dnpb.gov.ua/article/view/73256/74278.

13. Tkachenko H. M. Vykhovannia shkoliariv zasobamy slova u tvorchii spadshchyni V. O. Sukhomlynskoho [Education of the Schoolchildren by Means of a Word in the Creative Inheritance of V. O. Sukhomlynsky]/ Tkachenko Galyna Mykolaivna : dys. ... kand.. ped. n. : 13.00.01. - K., 1999. - 198 s.

14. Sahach H. M. V. O. Sukhomlynskyi pro mystetstvo slova pedahoha [V. O. Sykhomlynsky about Teacher's Art of Oratory] / H. M. Sahach // Slovo zhyvotvoriashche (dukhovni zasady pedahohichnoi rytoryky) [Life-Giving Word (Spiritual Concepts of Pedagogical Oratory)] : [navchal'nyi posibnyk]. - K. : Poshuk, 2000. - S. 215-223.

15. Abulkhanova-Slavskaia L. A. Vremia lychnosty i vremia zhyzny [Time of Personality and Time of Life]/ L. A. Abulkhanova-Slavskaia, T. N. Berezina. - SPB. : Alteiia, 2001.-304 s. 
16. Ilin V. I. Sotsyal'noie vremia i sotsyal'noie prostranstvo [Social Time and Social Space] / V. I. Ilin // Sotsyal'noie neravenstvo [Social Inequalities]. - Tsentr sotsiolohycheskoho obrazovaniia instytuta sotsiolohii RAN. - M. : Izd-vo Instytut sotsiolohii RAN, 2000. - S. 58-65.

17. Levyn K. Topolohiia i teoriia polia. Opredeleniie poniatiia pole v dannyi moment [Topology and Theory of Field. Definition of Term at the Moment] / Kurt Levyn // Istoriia psykholohii (10-30-e hh. Period otkrytoho kryzysa) : Teksty [The History of Psychology] / Pod red. P. Ia. Halperina, A. N. Zhdan. - 3-e yzd. - Ekaterinburh : Delovaia knyha, 1999. - S. 230-260.

18. Gurvitch G. The Spectrum of Social Time / Gurvitch G. - Holland : D.Reidel Publishing company, 1964. - 86 p.

19. Aheiev V. V. Mykhailo Braichevskyi : implikatyvna filosofiia ta filosofiia chasu [Mykhailo Braichevskyi : Implicative Philosophy and Philosophy of Time]/ V. V. Aheiev // Naukovi zapysky NaUKMA [The Scientific Papers NaUKMA]. - 2002. - T. 20 : Istorychni nauky : u 2ch. - Ch. 1. - S. 75-76.

20. Theory of Society / ed. by T. Parsons, E. Shils, K. D. Naegele, J. R. Pitts. N.Y. : The Free Press, 1961.

21. Reivenskroft K. Vstrecha s chudom. Rebenok otklykaetsia na pryrodku [Meeting with a Miracle. A Child Responds to the Nature] / Kelvyn Reivenskroft // Filosofiia dytynstva Yanusha Korchaka. Fundamental'ni potreby dytyny v suchasnomu suspilstvi [Janusz Korczak's Philosophy of Childchood. Children's Basic Needs in Modern Society] : [zbirnyk materialiv Mizhnarodnoi naukovoi konferentsii z pedahohiky ta dytiachoi psykholohii]. - K. : Dukh i litera, 2017. - S. 55-72.

22. Sukhomlynska O. V. Filosofiia dytynstva Yanusha Korchaka: yak my rozumiiemo yii sohodni [Janusz Korczak's Philosophy of Childchood. How Do We Understand It Today] / Olha Sukhomlynska // Filosofiia dytynstva Yanusha Korchaka. Fundamental'ni potreby dytyny v suchasnomu suspilstvi [Janusz Korczak's Philosophy of Childchood. Children's Basic Needs in Modern Society] : [zbirnyk materialiv Mizhnarodnoi naukovoi konferentsii z pedahohiky ta dytiachoi psykholohii]. - K. : Dukh i litera, 2017. - S. 22-29.

23. Korczak J. Jak kochac dziecko / Korczak Janusz. - Warszawa, 2012. - 174 s.

24. Sukhomlynskyi V. O. Yak vykhovaty spravzhniu liudynu [How to Bring Up a Real Person] / V. O. Sukhomlynskyi // Vybrani tvory : u 5t. [Selected Works in 5 Volumes]. - K. : Radians'ka shkola, 1977. - T. 2 - 149 s.

25. Sukhomlynskyi V. Neotlozhnyie problemy teorii i praktiki vospitaniia [Urgent Problems of Theory and Practice of Upbringing] / V. Sukhomlynskyi // Narodnoie obrazovaniie [Public Education]. - 1961. - №. 10. - S. 54-61.

26. Horbunov V. E. Sotsiolohiia vremeni : teoretyko-metodolohicheskiie aspekty analiza [Sociology of Time : Methodological-Theoretic Aspects of Analyses]: avtoref. dyss... kand.. sotsiol. n. : 22.00.01 - Teoriia, metodolohiia i istoriia sotsiolohii / Vladymyr Evhenevych Horbunov. - Saratov, 2000. - $22 \mathrm{~s}$.

27. Sukhomlynskyi V. O. Sertse viddaiu ditiam [My Heart I Give to Children] / Vasyl Sukhomlynskyi. - K. : Radians'ka shkola, 1972. $-244 \mathrm{~s}$.

28. Sukhomlynskyi V. O. Sto porad vchytelevi [One Hundred Pieces of Advise To Teachers] / V. O. Sukhomlynskyi // Vybrani tvory : V 5t. [Selected Works : in 5 Volumes].- T. 2. - K. : Radians'ka shkola, 1976. - $661 \mathrm{s.}$

29. Tsukanov B. I. Kachestvo vnutrennykh chasov i problema intellekta [Quality of Inner Hours and the Problem of Intellect] / B. I. Tsukanov // Psykholohycheskii zhurnal [Psychological Journal]. - 1991. - T. 12. - № 3. - S. 38-44.

30. Belenkaia L. Ya. K voprosu o vospryiatii vremennoi dlitel'nosti i eho narushenyiakh [On the Question of the Temporal Endurance and Its Defections] / L. Ya. Belenkaia // Issledovaniia po psykholohii vospriiatiia [Studies on the Perceptual Psychology]. - M. - L., 1948. - S. 342-358.

31. Nemirovskaia M. A. Razvitiie chuvstva vremeni : psykhoanaliticheskaia tochka zreniia [Development of Time Perception : Psychoanalitic Point of View]/ M. A. Nemirovskaia // Zhurnal praktycheskoi psykholohii i psykhoanaliza № 2 iiun 2003 [Journal of Experimental Psychology and Depth Psychology]. - № 6. - S. 15-19.

32. Tushnova T. V. O pamiati na vremia u detei razlichnoho shkol'noho vozrasta [About Memories Concerning Time and Children of Different Ages] / T. V. Tushnova // Fiziolohicheskiie mekhanyzmy vospriiatiia i otsenki vremeni : Uchionyie zapisky Bashkyrskoho hosudarstvennoho unyversyteta [Physiological Mechanisms of Perception and Time Judgement : Scientific Notes BSU]. - 1968. - Vyp. 24. Seriia biolohicheskaia - № 3. - S. 128-133.

33. Sukhomlynskyi V. O. Pro vykhovannia [On Education] / V. O. Sukhomlynskyi // Vybrani tvory : V 5t. [Selected Works : in 5 Volumes]. - T. 2. - K. : Radianska shkola, 1976. $-661 \mathrm{~s}$.

\section{Серадзкая-Базюр Б., Сейко Н. А. Темпоральные характеристики педагогики Василия Сухомлинского.}

В статье определены темпоральные характеристики педагогической теории и практики педагогической деятельности Василия Александровича Сухомлинского. Установлена связь между временем и ведущими педагогическими понятиями, которые находят свое место в теории

В. Сухомлинского - учебой, воспитанием, развитием личности ребенка. Выяснено темпоральное содержание ведущих процессуальных характеристик развития личности - деятельности, мышления, поведения и коммуникаџий. Установлены уровни функционирования темпоральной педагогики (время как период жизни человека; как понятие ежедневной жизни личности; как ценность). Сформулирован вывод о близости темпоральных идей Василия Сухомлинского и Януша Корчака.

Ключевые слова: Василий Сухомлинский, темпоральность, педагогическая теория. 


\section{Sieradzka-Baziur B., Seiko N. A. Temporal Characteristics of Vasyl Sukhomlynsky's Pedagogy.}

As the title implies the temporal characteristics of pedagogical theory and practice of Vasyl Sukhomlynsky's teaching activity are defined in the article. Much attention is given to V. Sukhomlynsky's main concepts and ideas concerning bringing up children. Further the author writes about the temporal characteristics of pedagogical theory and practice of $V$. Sukhomlynsky's teaching activity. Connection is set between time and leading pedagogical concepts that find their way in the theory of $V$. Sukhomlynsky, namely studies, education, development of child's personality. The main idea of the article is to determine the main temporal characteristics of $V$. Sukhomlynsky's pedagogy on the material of his main scientific works. Temporal content of leading procedural descriptions of personality's development is found out, they include activity, thinking, behavior and communications. The levels of temporal pedagogics functioning (for example time as a period of human life; as a concept of personality's daily life; as a value) are set. In conclusion the author writes about the closeness of the temporal ideas of Vasyl Sukhomlynsky and Janusz Korczak.

Key words: Vasyl Sukhomlynsky, temporality, pedagogical theory. 